\title{
PENGARUH PUPUK ORGANIK DAN JARAK TANAM TERHADAP PERTUMBUHAN DAN HASIL PADI PADA BUDIDAYA METODA SRI
}

\author{
Odang Hidayat *)
}

\begin{abstract}
ABSTRAK
Percobaan ini bertujuan untuk mengetahui pengaruh interaksi antara jenis pupuk organic dan jarak tanam terhadap pertumbuhan dan hasil tanaman padi dengan budidaya metoda SRI yang dilaksanakan di Desa Gunungmanik Kecamatan Tanjungsari Kabupaten Sumedang. percobaan dimulai dari bulan Desember 2009 sampai dengan April 2010

Rancangan percobaan yang digunakan adalah Rancangan Petak Terbagai. Dengan 12 Kombinasi perlakuan yang terdiri dari anak petak utama berupa jenis pupuk organic (: $a_{1}=$ pupuk kandang ayam, $a_{2}=$ pupuk kandang domba, dan $a_{3}=$ kompos limbah pasar). Anak petak berupa jarak tanam $\left(b_{1}=25 \mathrm{~cm} \times 25 \mathrm{~cm}, b_{2}=30 \mathrm{~cm} \times 30 \mathrm{~cm}, b_{3}=60 \mathrm{~cm}\right.$ $x 30 \mathrm{~cm} \times 30 \mathrm{~cm}$, dan $b_{4}=60 \mathrm{~cm} \times 30 \mathrm{~cm} \times 15 \mathrm{~cm}$.

Hasil percobaan menunjukkan terjadi interaksi antara pupuk organic dan jarak tanam terhadap pertumbuhan dan hasil padi pada budidaya metoda SRI. Penggunaan jarak tanam $60 \times 30 \times 15$, diikuti dengan pemberian pupuk kandang ayam 10 ton.Ha ${ }^{-1}$ memberikan pertumbuhan terbaik terhadap jumlah anakan, jumlah malai produktif per rumpun, bobot 1000 bulir gabah, dan bobot gabah kering panen per petak. Penggunaan jarak tanam $60 \times 30 \times 15$ yang diikuti dengan pemberian pupuk kandang ayam 10 ton. $\mathrm{Ha}^{-1}$ dan Penggunaan jarak tanam $60 \times 30$ $x 15$ yang diikuti dengan pemberian kompos limbah pasar 10 ton. $\mathrm{Ha}^{-1}$, menghasilkan gabah kering panen paling tinggi.
\end{abstract}

Kata kunci: padi, pupuk organik, jarak tanam, pertumbuhan, hasil 


\section{PENDAHULUAN}

Intensifikasi dengan menggunakan pupuk sintesis dan pestisida secara tidak tepat dan secara terus menerus tidak disadari dapat menurunkan kemampuan lahan dalam mendukung pertumbuhan dan hasil tanaman. Untuk mengatasi permasalahan tersebut dan membangun sektor pertanian, khususnya pangan ke depan yang ramah lingkungan dan menghasilkan produk yang aman konsumsi sesuai dengan tuntutan pasar global, maka penerapan usahatani non sintetik merupakan suatau prospek, salah satunya yaitu dengan menerapkan metode SRI (System of Rice Intensification).

Metode SRI menerapkan konsep-konsep organik yang ramah lingkungan, yaitu dengan menggunakan pupuk organik untuk memberikan nutrisi pada tanaman dan pestisida hayati sebagai pengendali hama dan penyakit yang mengganggu tanaman. Penerapan metode SRI menupakan salah satu solusi untuk menanggulangi dampak yang ditimbulkan dari penggunaan pup sk buatan yang berlebihan dan sarana pertanian modern lainnya terhadap lingkungan. Pertanian jenis ini mengandalkan kebutuhan hara melalui pupuk organik dan masukan-masukan alami lainnya (Irsal Las, 2006).

Pupuk organik digunakan untuk meningkatkan kesuburan tanah, meningkatkan kadar bahan organik tanah, menyediakan hara mikro, dan memperbaiki struktur tanah. Penggunaan bahan-bahan ini juga dapat meningkatkan pertumbuhan mikroba dan perputaran hara dalam tanah (Badan Litbang Pertanian, 2006)

Pengaturan jarak tanam merupakan salah satu cara pengaturan populasi tanaman, yang dapat memberikan keleluasaan terhadap tanaman untuk dapat tumbuh lebih baik karena terhindar dari persaingan baik dengan tanaman itu sendiri, maupun dengan gulma yang tumbuh sehingga dapat meningkatkan hasil, untuk itu maka perlu dilakukan penelitian penggunaan pupuk organic maupun pengaturan jarak tanam pada budidaya tanaman padi dengan metode SRI

\section{TUJUAN PENELITIAN}

Tujuan penelitian ini adalah untuk mempelajari pengaruh pemberian pupuk organik dan jarak tanam yang berbeda terhadap pertumbuhan dan hasil tanaman padi dengan metode SRI. 


\section{KERANGKA PEMIKIRAN}

SRI (System of Rice Intensification) adalah suatu cara budidaya tanaman padi yang intensif dan efisien dengan proses manajemen sistem perakaran yang berbasis pada pengelolaan air, tanah dan tanaman. Pada metoda SRI semua unsur dalam tanaman padi dikembangkan dengan cara memberikan kondisi yang sesuai untuk pertumbuhannya, diantaranya pupuk yang berupa pupuk organik dan pengaturan jarak tanam untuk menciptakan kondisi lingkungan yang lebih baik guna memberikan ruang tumbuh yang memadai.

Pupuk organik merupakan bahan pembenah tanah yang mengadung hara $\mathrm{N}, \mathrm{P}, \mathrm{K}$ rendah tapi mengandung hara mikro dalam jumlah cukup yang sangat diperlukan untuk pertumbuhan tanaman. Sebagai pembenah tanah, pupuk organik dapat meningkatkan kesuburan tanah baik fisik, kimia, maupun hayati . Menurut Sutanto (2002) puppuk organik dapat mencegah terjadinya erosi, pergerakan permukaan tanah dan retakan tanah, serta mempertahankan kelengasan tanah.

Jarak tanam berhubungan dengan kepadatan populasi yang berhubungan dengan produksi tanaman persatuan luas, hal ini berhubungan dengan kompetisi tanaman dalam mendapatkan unsur hara, air, serta efisiensi dalam penggunaan cahaya matahari (Bambang dkk, 2003).

Peningkatan kerapatan populasi tanaman persatuan luas pada suatu batas tertentu dapat meningkatkan hasil tanaman, namun penambahan jumlah tanaman selanjutnya akan menurunkan hasil karena terjadi kompetisi unsur hara, air, ruang tumbuh dan sinar matahari (Mintarsih dkk, 1989).

Dengan pemberian pupuk organik penyedia unsur hara dan mengatur jarak tanam sedemikian rupa, keadaan lingkungan dapat dimanfaatkan seefisien mungkin maka akan diperoleh hasil fotosintesis yang semakin besar. Fotosintat tersebut sangat menentukan hasil biji karena sebagian fotosintat ditimbun dalam biji. Selama periode pengisian biji terjadi peningkatan akumulasi bahan kering dan kekurangan hara pada periode ini akan menyebabkan biji tidak berkembang penuh. Tersedianya hara yang cukup sepanjang pertumbuhan tanaman, dalam hal ini dengan pemberian pupuk organik memberikan kemungkinan tanaman menimbun bahan kering yang lebih banyak.

Setiap jenis pupuk organik memiliki kandungan unsur hara yang berbeda-beda, sehingga akan berpengaruh terhadap pemakaian jarak tanam untuk mendapatkan hasil yang terbaik pun akan berbeda-beda pula. Oleh 
karena itu pemberian pupuk organik dan pengaturan jarak tanam merupakan suatu alternatif yang perlu dipertimbangkan dalam usaha meningkatkan hasil padi dengan metode SRI, Hasil penelitian Tata Sasmita (2005), pada metoda SRI kecepatan tumbuhnya relatife tinggi, dikarenakan dalam SRI digunakan pupuk dasar yaitu pupuk organik, jarak tanam yang lebar dan keadaan air yang tidak menggenang.

\section{BAHAN DAN METODA}

Penelitian menggunakan metoda eksperimen yang di lakukan di di Desa Gunungmanik Kecamatan Tanjungsari Kabupaten Sumedang, percobaan dimulai dari bulan Desember 2009 sampai dengan April 2010

Bahan dan alat yang digunakan adalah, benih padi IR 64, pupuk organik (pupuk kandang domba, pupuk kandang ayam, dan kompos limbah pasar), cangkul, mistar, timbangan analitik, oven, tali rapia, baki plastik, kantong plastic, kertas, alat tulis, karung dan alat pengukur kadar air (Grain Moisture Meter).

Rancangan percobaan yang digunakan adalah Rancangan Petak Terbagai. Dengan 12 Kombinasi perlakuan terdiri dari anak petak utama berupa jenis pupuk organic $\left(: a_{1}=\right.$ pupuk kandang ayam, $a_{2}=$ pupuk kandang domba, dan $\mathrm{a}_{3}=$ kompos limbah pasar) dan anak petak berupa jarak tanam $\left(b_{1}=25 \mathrm{~cm} \times 25 \mathrm{~cm}, b_{2}=30 \mathrm{~cm} \times 30 \mathrm{~cm}, b_{3}=60 \mathrm{~cm} \times 30 \mathrm{~cm} \times 30 \mathrm{~cm}\right.$, dan $\mathrm{b}_{4}=60 \mathrm{~cm} \times 30 \mathrm{~cm} \times 15 \mathrm{~cm}$.

Rancangan respon dilakukan terhadap : a) Jumlah anakan per rumpun, b) Jumlah malai yang produktif per rumpun, c) Jumlah gabah per malai, d) Bobot 1000 butir biji, dan e) Bobot gabah kering panen per petak,

\section{HASIL DAN PEMBAHASAN}

\section{Jumlah Anakan per Rumpun}

Terjadi interaksi antara pemberian pupuk organik dan jarak tanam terhadap jumlah anakan per rumpun pada umur 50, 60, 70 HST. (tabel 1, 2, dan 3).

Interaksi antara pupuk organic dan jarak tanam nyata mempengaruhi jumlah anakan. Hal ini dapat terjadi karena pemberian pupuk organic dapat meningkatkan kesuburan tanah, sedangkan jarak tanam dapat memberikan ruang tumbuh yang lebih baik sehingga perkembangan akar semakin baik yang dapat memacu jumlah anakan semakin banyak. 
Tabel 1.

Pertumbuhan dan Hasil Tanaman Padi dengan Metode SRI, akibat Pemberian Pupuk Organik dan Jarak Tanam yang Berbeda terhadap Jumlah Anakan per Rumpun Umur 50 HST.

\begin{tabular}{|c|c|c|c|c|}
\hline \multirow[b]{2}{*}{ Perlakuan } & \multicolumn{4}{|c|}{ Rata-rata Jmlah Anakan per Rumpun } \\
\hline & $\begin{array}{c}\mathrm{b}_{1} \\
(25 \times 25 \mathrm{~cm})\end{array}$ & $\begin{array}{c}b_{2} \\
(30 \times 30 \mathrm{~cm})\end{array}$ & $\begin{array}{r}\mathrm{b}_{3}(60 \mathrm{~cm} \mathrm{x} \\
30 \times 30 \mathrm{~cm})\end{array}$ & $\begin{array}{l}\mathrm{b}_{4}(60 \mathrm{~cm} \mathrm{x} \\
30 \times 15 \mathrm{~cm})\end{array}$ \\
\hline$a_{1}$ (pupuk kandang ayam) & $\begin{array}{rr}14,00 & c \\
B & \end{array}$ & $\begin{array}{rr}13,90 & b \\
\text { B } & \end{array}$ & $\begin{array}{r}12,50 \\
\mathrm{~A}\end{array}$ & $\begin{array}{rr}13,90 & b \\
\text { B } & \end{array}$ \\
\hline$a_{2}$ (pupuk kandang domba) & $\begin{array}{r}10,70 \quad \text { a } \\
\mathrm{A}\end{array}$ & $\begin{array}{r}11,70 \quad \mathrm{a} \\
\mathrm{B}\end{array}$ & $\begin{array}{r}11,80 \text { a } \\
\text { B }\end{array}$ & $\begin{array}{r}10,10 \quad \mathrm{a} \\
\mathrm{A}\end{array}$ \\
\hline$a_{3}$ (kompos limbah pasar) & $\begin{aligned} 13,50 & \text { b } \\
A & \end{aligned}$ & $\begin{array}{rl}13,30 & b \\
A & \end{array}$ & $\begin{array}{r}13,80 \quad \text { b } \\
\text { A }\end{array}$ & $\begin{array}{rl}13,80 & b \\
A & \end{array}$ \\
\hline
\end{tabular}

Keterangan : Angka rata-rata yang diikuti huruf kecil ( arah vertikal) dan huruf kapital (arah horizontal) yang sama berbeda tidak nyata menurut Uji Jarak Berganda Duncan pada taraf nyata $5 \%$

Tabel 2.

Pertumbuhan dan Hasil Tanaman Padi dengan Metode SRI, akibat Pemberian Pupuk Organik dan Jarak Tanam yang Berbeda terhadap Jumlah Anakan per Rumpun Umur 60 HST.

\begin{tabular}{|c|c|c|c|c|}
\hline \multirow[b]{2}{*}{ Perlakuan } & \multicolumn{4}{|c|}{ Rata-rata Jumlah Anakan per Rumpun } \\
\hline & $\begin{array}{c}\mathrm{b}_{1} \\
(25 \times 25 \mathrm{~cm})\end{array}$ & $\begin{array}{c}\mathrm{b}_{2} \\
(30 \times 30 \mathrm{~cm})\end{array}$ & $\begin{array}{r}b_{3}(60 \mathrm{~cm} \mathrm{x} \\
(30 \times 30 \mathrm{~cm})\end{array}$ & $\begin{array}{l}\mathrm{b}_{4}(60 \mathrm{~cm} \mathrm{x} \\
(30 \times 15 \mathrm{~cm})\end{array}$ \\
\hline$a_{1}$ (pupuk kandang ayam) & $\begin{array}{rr}14,00 & \mathrm{c} \\
\mathrm{B} & \end{array}$ & $\begin{array}{rl}14,60 & b \\
A & \end{array}$ & $\begin{array}{r}14,10 \quad \mathrm{a} \\
\mathrm{A}\end{array}$ & $\begin{array}{rl}17,60 & b \\
C & \end{array}$ \\
\hline$a_{2}$ (pupuk kandang domba) & $\begin{array}{r}11,50 \quad \mathrm{a} \\
\mathrm{A}\end{array}$ & $\begin{array}{r}13,00 \quad a \\
B\end{array}$ & $\begin{array}{r}14,60 \text { a } \\
\text { B }\end{array}$ & $\begin{array}{r}11,00 \text { a } \\
\mathrm{A}\end{array}$ \\
\hline$a_{3}$ (kompos limbah pasar) & $\begin{array}{rl}16,50 & c \\
A & \end{array}$ & $\begin{array}{rl}15,70 & b \\
A & \end{array}$ & $\begin{array}{r}16,50 \quad c \\
A\end{array}$ & $\begin{array}{rl}17,10 & b \\
A & \end{array}$ \\
\hline
\end{tabular}

Keterangan : Angka rata-rata yang diikuti huruf kecil ( arah vertikal) dan huruf kapital (arah horizontal) yang sama berbeda tidak nyata menurut Uji Jarak Berganda Duncan pada taraf nyata $5 \%$

Jumlah anakan per rumpun pada umur 50 HST yang tertinggi diperolah dari perlakuan pemberian pupuk ayam yang diikuti dengan jarak tanam 25 $\mathrm{cm} \times 25 \mathrm{~cm}$. Sedangkan pada umur $60 \mathrm{HST}$ jumlah anakan per rumpun yang tertinggi diperolah dari perlakuan pemberian pupuk ayam yang diikuti dengan jarak tanam $60 \times 30 \times 15$. Pada umur 70 HST jumlah anakan per 
rumpun yang tertinggi diperolah dari perlakuan pemberian pupuk ayam yang diikuti dengan jarak tanam $60 \times 30 \times 15$ dan pemberian pupuk kandang domba yang diikuti dengan jarak $60 \times 30 \times 15$. Hal ini disebabkan karena pupuk ayam dan domba memiliki kandungan unsur $\mathrm{P}$ dan $\mathrm{N}$ lebih tinggi bila dibandingkan dengan pupuk kompos sampah pasar.

Tabel 3.

Pertumbuhan dan Hasil Tanaman Padi dengan Metode SRI, akibat Pemberian Pupuk Organik dan Jarak Tanam yang Berbedaterhadap Jumlah Anakan per Rumpun Umur 70 HST.

\begin{tabular}{|c|c|c|c|c|}
\hline \multirow[b]{2}{*}{ Perlakuan } & \multicolumn{4}{|c|}{ Rata-rata Jumlah Anakan per Rumpun } \\
\hline & $\begin{array}{c}\mathrm{b}_{1} \\
(25 \times 25 \mathrm{~cm})\end{array}$ & $\begin{array}{c}b_{2} \\
(30 \times 30 \mathrm{~cm})\end{array}$ & $\begin{array}{r}\mathrm{b}_{3}(60 \mathrm{~cm} \mathrm{x} \\
(30 \times 30 \mathrm{~cm})\end{array}$ & $\begin{array}{l}\mathrm{b}_{4} \quad(60 \mathrm{~cm} x \\
(30 \times 15 \mathrm{~cm})\end{array}$ \\
\hline$a_{1}$ (pupuk kandang ayam) & $\begin{array}{rr}14,00 & c \\
B & \end{array}$ & $\begin{array}{rr}14,60 & b \\
A & \end{array}$ & $\begin{array}{rr}14,10 & a \\
A & \end{array}$ & $\begin{array}{rr}17,60 & b \\
C & \end{array}$ \\
\hline $\mathrm{a}_{2}$ (pupuk kandang domba) & $\begin{array}{r}11,50 \quad \mathrm{a} \\
\mathrm{A}\end{array}$ & $\begin{array}{r}13,00 \quad \mathrm{a} \\
\mathrm{B}\end{array}$ & $\begin{array}{r}14,60 \quad a \\
B\end{array}$ & $\begin{array}{r}11,00 \quad \mathrm{a} \\
\mathrm{A}\end{array}$ \\
\hline$a_{3}$ (kompos limbah pasar) & $\begin{array}{r}16,50 \quad \mathrm{c} \\
\mathrm{A}\end{array}$ & $\begin{array}{rl}15,70 & b \\
A & \end{array}$ & $\begin{array}{rl}16,50 & c \\
A & \end{array}$ & $\begin{array}{rl}17,10 & b \\
A & \end{array}$ \\
\hline
\end{tabular}

Keterangan : Angka rata-rata yang diikuti huruf kecil ( arah vertikal) dan huruf kapital (arah horizontal) yang sama berbeda tidak nyata menurut Uji Jarak Berganda Duncan pada taraf nyata $5 \%$

Dermiyati (1997), menjelaskan bahwa bahan organik mampu berfungsi sebagai energi dan makanan bagi mikroorganisme tanah. Seiring dengan perombakan bahan organik yang dilakukan mikroorganisme akan terjadi pelepasan N, P dan K yang dibutuhkan tanaman (Brady dan Buckman, 1983).

Perombakan bahan organik menghasilkan juga asm-asam organik seperti asam humat dan fulvat yang berperan penting dalam mengkelat Fe dan Al tanah, sehingga ketersediaan P akan meningkat (Subba Rao, 1995). kondisi ini turut berdampak pada pertumbuhan tanaman padi yang membutuhkan unsur hara terutama N dan P. De Datta (1981), menyatakan bahwa unsur hara posfor yang diserap tanaman salah satu fungsinya adalah membantu dalam pembentukan anakan.

Perombakan bahan organik menghasilkan juga asm-asam organik seperti asam humat dan fulvat yang berperan penting dalam mengkelat Fe dan Al tanah, sehingga ketersediaan P akan meningkat (Subba Rao, 1995). kondisi ini turut berdampak pada pertumbuhan tanaman padi yang 
membutuhkan unsur hara terutama N dan P. De Datta (1981), menyatakan bahwa unsur hara posfor yang diserap tanaman salah satu fungsinya adalah membantu dalam pembentukan anakan.

\section{Jumlah Malai Produktif per Rumpun}

Terjadi interaksi antara pemberian pupuk organik dan jarak tanam terhadap jumlah mailai produktif per rumpun tanaman padi pada budidaya metoda SRI. (tabel 4).

Tabel 4.

Pertumbuhan dan Hasil Tanaman Padi dengan Metode SRI, Akibat Pemberian Pupuk Organik dan Jarak Tanam yang Berbeda terhadap Jumlah Malai produktif per Rumpun

\begin{tabular}{|c|c|c|c|c|}
\hline \multirow{3}{*}{$\begin{array}{l}\text { Perlakuan } \\
\mathrm{a}_{1} \text { (pupuk kandang ayam) }\end{array}$} & \multicolumn{4}{|c|}{ Rata-rata Jumlah Malai Produktif per Rumpun } \\
\hline & $\begin{array}{c}b_{1} \\
(25 \times 25 \mathrm{~cm})\end{array}$ & $\begin{array}{c}b_{2} \\
(30 \times 30 \mathrm{~cm})\end{array}$ & $\begin{array}{r}\mathrm{b}_{3}(60 \mathrm{~cm} \mathrm{x} \\
(30 \times 30 \mathrm{~cm})\end{array}$ & $\begin{array}{l}b_{4}(60 \mathrm{~cm} \mathrm{x} \\
(30 \times 15 \mathrm{~cm})\end{array}$ \\
\hline & $\begin{array}{r}13,40 \quad \mathrm{a} \\
\mathrm{A}\end{array}$ & $\begin{array}{r}18,60 \quad \mathrm{a} \\
\mathrm{A}\end{array}$ & $\begin{array}{rr}24,00 & c \\
B & \end{array}$ & $\begin{array}{rr}21,50 & \mathrm{c} \\
\mathrm{B} & \end{array}$ \\
\hline $\mathrm{a}_{2}$ (pupuk kandang domba) & $\begin{array}{r}10,00 \quad a \\
A\end{array}$ & $\begin{array}{r}18,80 \quad a \\
B\end{array}$ & $\begin{array}{r}16,40 \quad \mathrm{a} \\
\mathrm{B}\end{array}$ & $\begin{array}{rl}15,80 & b \\
A & \end{array}$ \\
\hline $\mathbf{a}_{3}$ (kompos limbah pasar) & $\begin{array}{rl}16,70 & b \\
A & \end{array}$ & $\begin{array}{r}18,60 \quad \mathrm{a} \\
\mathrm{A}\end{array}$ & $\begin{array}{rl}20,60 & b \\
A & \end{array}$ & $\begin{array}{rl}15,90 & b \\
A & \end{array}$ \\
\hline
\end{tabular}

Keterangan : Angka rata-rata yang diikuti huruf kecil ( arah vertikal) dan huruf kapital (arah horizontal) yang sama berbeda tidak nyata menurut Uji Jarak Berganda Duncan pada taraf nyata $5 \%$

Berdasarkan tabel 4 jumlah malai yang produktif per rumpun yang tertinggi diperolah dari perlakuan pemberian pupuk ayam yang diikuti dengan jarak tanam $60 \times 30 \times 30$, dan $60 \times 30 \times 15$. Hal ini disebabkan pupuk ayam memiliki kandungan unsur $\mathrm{P}$ yang paling tinggi bila di banding dengan pupuk organik yang lain. Menurut Doberman dan fairhust (2000), Kahat P dapat meningkatkan jumlah gabah hampa, menurunkan bobot dan kualitas gabah, serta menghambat pemasakan. Dalam keadaan kahat $\mathrm{P}$ yang berat, tanaman padi tidak dapat berbunga. Kekurangan $\mathrm{P}$ juga menurunkan tanggap tanaman terhadap pemupukan N. Selain itu kahat $\mathrm{P}$ seringkali berasosiasi dengan meningkatnya kadar $\mathrm{Fe}$, sehingga meracuni tanaman dan kekurangan $\mathrm{Zn}$, terutama pada tanah ber-pH rendah. Menurut Manurung dan Ismunadji (1988), unsur P dan K membantu dalam perkembangan akar dan pembentukan anakan produktif. 


\section{Jumlah Gabah per Malai}

Terjadi interaksi antara pemberian pupuk organic dan jarak tanam terhadap jumlah gabah per malai yang produktif ( tabel 5).

\section{Tabel 5.}

Pertumbuhan dan Hasil Tanaman Padi dengan Metode SRI, Akibat Pemberian Pupuk Organik dan Jarak Tanam yang Berbeda terhadap Jumlah Gabah per Malai

\begin{tabular}{|c|c|c|c|c|}
\hline \multirow[b]{2}{*}{ Perlakuan } & \multicolumn{4}{|c|}{ Rata-rata Jumlah Malai Produktif per Rumpun } \\
\hline & $\begin{array}{c}\mathrm{b}_{1} \\
(25 \times 25 \mathrm{~cm})\end{array}$ & $\begin{array}{c}\mathrm{b}_{2} \\
(30 \times 30 \mathrm{~cm})\end{array}$ & $\begin{array}{r}\mathrm{b}_{3}(60 \mathrm{~cm} \mathrm{x} \\
(30 \times 30 \mathrm{~cm})\end{array}$ & $\begin{array}{l}\mathrm{b}_{4}(60 \mathrm{~cm} \mathrm{x} \\
(30 \times 15 \mathrm{~cm})\end{array}$ \\
\hline$a_{1}$ (pupuk kandang ayam) & $\begin{array}{rr}50,94 & \text { a } \\
\text { A } & \end{array}$ & $\begin{array}{c}78,26 \text { b } \\
\text { B }\end{array}$ & $\begin{aligned} 85,49 & \text { b } \\
\text { B } & \end{aligned}$ & $\begin{array}{rl}81,61 & b \\
\text { B } & \end{array}$ \\
\hline $\mathrm{a}_{2}$ (pupuk kandang domba) & $\begin{aligned} 59,40 & \text { a } \\
\mathrm{A} & \end{aligned}$ & $\begin{array}{r}66,45 \quad \mathrm{a} \\
\mathrm{A}\end{array}$ & $\begin{aligned} 80,37 & \text { a } \\
\text { B } & \end{aligned}$ & $\begin{array}{r}80,55 \quad \text { a } \\
\text { B }\end{array}$ \\
\hline $\mathrm{a}_{3}$ (kompos limbah pasar) & $\begin{array}{rl}72,97 & \mathrm{~b} \\
\mathrm{~A} & \end{array}$ & $\begin{array}{rl}83,86 & \mathrm{c} \\
\mathrm{A} & \end{array}$ & $\begin{array}{c}120,21 \quad \mathrm{c} \\
\mathrm{B}\end{array}$ & $\begin{array}{c}104,52 \text { b } \\
\text { B }\end{array}$ \\
\hline
\end{tabular}

Keterangan : Angka rata-rata yang diikuti huruf kecil ( arah vertikal) dan huruf kapital (arah horizontal) yang sama berbeda tidak nyata menurut Uji Jarak Berganda Duncan pada taraf nyata $5 \%$

Jumlah gabah per malai yang produktif tertinggi diperoleh dari perlakuan pemberian pupuk kompos limbah pasar yang diikuti dengan jarak tanam $60 \times 30 \times 30$, keadaan ini terjadi karena pupuk kompos limbah pasar memiliki kandungan $\mathrm{Cu}$ yang lebih tinggi dibandingkan dengan kandungan $\mathrm{Cu}$ pupuk organic yang lainnya. Menurut Doberman dan Fairhurst (2000), tembaga $(\mathrm{Cu})$ membantu dalam mengkatalisis electron dan pemecahan molekul air yang menghasilkan energy pada fotosisntesis, sehingga yang diperlukan dalam pembentukan biji akan lebih banyak dan mengurangi biji hampa. Hasil penelitian Radjagukguk (1990) kehampaan gabah padi sawah disebabkabn oleh adanya kekahatan unsure mikro $\mathrm{Cu}$.

\section{Bobot 1000 Bulir Gabah}

Hasil analisis pertumbuhan dan hasil tanaman padi dengan metode SRI, akibat pemberian pupuk organik dan jarak tanam yang berbeda terhadap bobot 1000 bulir gabah menunjukkan ineraksi (tabel 6).

Berdasarkan tabel 6 , bobot 1000 butir yang paling tinggi di capai oleh perlakuan pupuk ayam diikuti dengan jarak tanam $60 \times 30 \times 15$. 
Sedangkan bobot 1000 butir terendah di perolah dari perlakuan pupuk ayam diikuti jarak tanam $30 \times 30$.

Donald dalam Gadner dkk (1991), mengatakan bahwa jarak tanam dengan kerapatan rendah kompetisis antar tanaman dan kompetisi dalam tubuh tanaman tidak ada selama awal pertumbuhan, namun dengan berlangsungnya pertumbuhan, maka terjadi sedikit kompetisi antar tanaman dan lebih sedikit lagi kompetisi dalam tubuh tanaman sampai setelah masa berbunga dan pembentukan biji, terjadinya kompetisi antar biji akan hasil asimilasi, berakibat lebih sedikit biji yang terbentuk dan mengecilnya ukuran biji.

Menurut Berger (1962), berat 1000 biji dipengaruhi oleh ukuran biji, bentuk biji dan kandungan biji. Ukuran biji sangat ditentukan oleh faktor genetis. Oleh karena itu, diduga hasil fotosintesis yang berkurang akibat terbatasnya unsur $\mathrm{N}$ cenderung mempengaruh bentuk biji sehingga menurunkan bobot 1000 biji.

Tabel 6.

Pertumbuhan dan Hasil Tanaman Padi dengan Metode SRI, Akibat Pemberian Pupuk Organik dan Jarak Tanam yang Berbeda terhadap Bobot 1000 Bulir gabah (g)

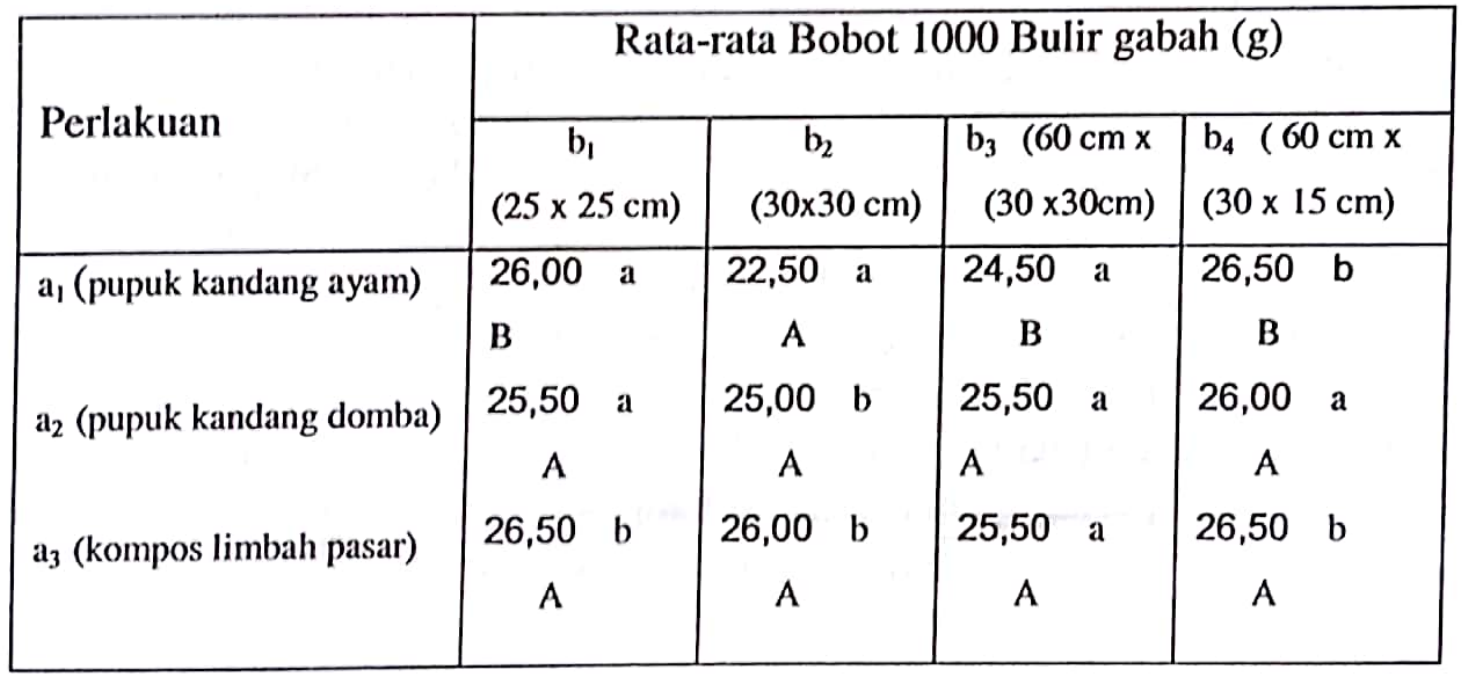

Keterangan : Angka rata-rata yang diikuti huruf kecil ( arah vertikal) dan huruf kapital (arah horizontal) yang sama berbeda tidak nyata menurut Uji Jarak Berganda Duncan pada taraf nyata $5 \%$

\section{Bobot Gabah Kering Panen}

Hasil analisis pertumbuhan dan hasil tanaman padi dengan metode SRI, akibat pemberian pupuk organik dan jarak tanam yang berbeda terhadap bobot gabah kering panen menunjukkan ineraksi (tabel 7.). 
Tabel 7.

Pertumbuhan dan Hasil Tanaman Padi dengan Metode SRI, Akibat Pemberian Pupuk Organik dan Jarak Tanam yang Berbeda terhadap Bobot Gabah Kering Panen per Petak $(\mathrm{Kg})$

\begin{tabular}{|c|c|c|c|c|}
\hline \multirow{2}{*}{ Perlakuan } & \multicolumn{4}{|c|}{ Rata-rata Bobot Gabah Kering Panen } \\
\hline & $\begin{array}{c}b_{1} \\
(25 \times 25 \mathrm{~cm})\end{array}$ & $\begin{array}{c}b_{2} \\
(30 \times 30 \mathrm{~cm})\end{array}$ & $\begin{array}{l}b_{3}(60 \mathrm{~cm} x \\
(30 \times 30 \mathrm{~cm})\end{array}$ & $\begin{array}{l}\mathrm{b}_{4}(60 \mathrm{~cm} x \\
(30 \times 15 \mathrm{~cm})\end{array}$ \\
\hline $\begin{array}{l}a_{1} \text { (pupuk kandang ayam) } \\
a_{2} \text { (pupuk kandang domba) } \\
a_{3} \text { (kompos limbah pasar) }\end{array}$ & $\begin{array}{cc}7,29 & \text { b } \\
\text { A } \\
6,79 & a \\
\text { A } & \\
i 0,96 & c \\
\text { B } & \end{array}$ & $\begin{array}{c}8,40 \quad{ }^{2} \\
\mathrm{~A}^{2} \\
7.45 \quad \mathrm{a} \\
\mathrm{A} \\
10,10 \mathrm{~b} \\
\mathrm{~A}\end{array}$ & $\begin{array}{c}10,00 \mathrm{~b} \\
\mathrm{~B} \\
7,50 \mathrm{a} \\
\mathrm{A} \\
8,88 \mathrm{~b} \\
\mathrm{~A}\end{array}$ & $\begin{array}{c}10,97 \quad b \\
\text { C } \\
9,49 \quad a \\
\text { B } \\
11,71 \quad b \\
\text { C }\end{array}$ \\
\hline
\end{tabular}

Keterangan : Angka rata-rata yang owkut huruf kecil ( arah vertikal) dan huruf kapital (arah horizontal) yang sama berbeda tidak nyata menurut Uji Jarak Berganda Duncan pada taraf nyata $5 \%$

Bobot gabah kering panen per petak paling tinggi dicapai oleh perlakuan pupuk kandang ayam dan kompos limbah pasar dengan jatak tanam 60 $\mathrm{x} 30 \times 15$. Tingginya hasil tersebut dikarenakan pada perlakuan pupuk kandang ayam menunjukkan pertumbuhan seperti jumlah anakan, jumlah malai produktif, jumlah gabah permalai yang lebih baik dibandingkan dengan perlakuan yang lain. Sedangkan pada perlakuan kompos limbah pasar diakibatkan oleh hasil bobot bulir yang lebih baik. Keadaan ini juga kemungkinan dikarenakan perlakuan kompos pasar dan jarak tanam 60 × 30 x 15 yang menunjukkan jumlah gabah permalai yang lebih baik walaupun tidak menunjukkan jumlah anakan terbanyak. Hal ini sejalan dengan pendapat Manurung dan Ismunadji (1988), dimana kapasitas hasil dapat dinaikkan tanpa pertumbuhan vegetatif yang berlebih, karena pertumbuhan vegetatif yang berlebih menyebabkan suplai asimilat berkurang yang bisa menyebabkan banyaknya bulir yang hampa. Tanaman yang memiliki anakan sedikit akan mempunyai saat pembungaan dan panen serempak, dan malai lebih seragam.

\section{KESIMPULAN DAN SARAN}

\section{Kesimpulan}

a. Terjadi interaksi antara pupuk organik dan jarak tanam terhadap pertumbuhan dan hasil padi pada budidaya metoda SRI 
b. Penggunaan jarak tanam $60 \times 30 \times 15$, diikuti dengan pemberian pupuk kandang ayam 10 ton. $\mathrm{Ha}^{-1}$ memberikan pertumbuhan terbaik terhadap jumlah anakan, jumlah malai produktif per rumpun, bobot 1000 bulir gabah, dan bobot gabah kering panen per petak. Penggunaan jarak tanam $60 \times 30 \times 30$, diikuti dengan pemberian pupuk kompos limbah pasar 10 ton. $\mathrm{Ha}^{-1}$ memberikan Jumlah gabah per malai yang produktif tertinggi

c. Penggunaan jarak tanam $60 \times 30 \times 15$, baik yang diikuti dengan pemberian pupuk kandang ayam 10 ton. $\mathrm{H}^{\mathrm{a}-\mathrm{I}}$ dan kompos limbah pasar 10 ton. $\mathrm{H}^{\mathrm{a}-1}$, menghasilkan gabah kering panen paling tinggi.

\section{Saran}

Pada budidaya padi metoda SRI pemberian jenis pupuk organic bisa pupuk kandang ayam atau kompos limbah pasar dengan menggunakan jarak tanam $60 \times 30 \times 15$. Namun, sebaiknya dilakukan penelitian kembali di tempat dan waktu yang berbeda.

\section{DAFTAR PUSTAKA}

Dermiyati.1997. Pengaruh Mulsa Terhadap Aktivitas Mikroorganisme Tanah dan Produksi jagung Hibrida C-1. Jurnal Tanah Tropik. 5 : 63-68.

De Detta, S. K. 1981. Priciples and Practies of Rice Production. Jhon Wiley and Son, New York.

Dinas Sumber Daya Air dan Pertambangan Kabupaten Garut. 2003. Efisiensi

Air Irigasi Melalui Metode System of rice intensification (SRI). DinasSumber Daya Air dan Pertambangan Kabupaten Garut. Sub Dinas Bina Manfaat dan Bia Teknik. Garut.

Dobermann, A., dan T. Fairhurst. 2000. Rice, Nutrient disorders and Nutrient Management. Handbook Series. Potash and Phosphote Institue (PPI), Potash and phosphate Institute of Canada (PPIC) and international Rice Research Institute. hlm 191.

Gardner. F.P, R.B.Perace, and R.L. Mitchell. 1991. Fisiologi Tanaman Budidaya. Terjemanan Herawati Susilo. UI Press, Jakarta. 428 hal 1.

Masdar, Muskar Kasim, Bujang Rusman, Nurhajati hakim dan Helmi. 2006. Tingkat Hasil dan Komponen Hasil Sistem Intensifikasi Padi Pupuk Organik di Daerah Curah Hujan Tinggi, dalam Jurnal IlmuIlmu Pertanian Indonesia. volume 8, no. 2, 2006. hlm 126-131. 
Sutanto, R. 2002. Pertanian Organik Menuju Pertanian Alternatif dan Berkelanjutan. Kanisius, Jakarta.

Tata Sasmita. 2005. Pengaruh Lamanya Benih Dipersemaian terhadap Pertumbuhan dan Hasil Padi Sawah Kultivar Ciherang pada Metode SRI dalam Skripsi, Fakultas Pertanian Unwim, Tanjungsari. Hal 46.

*) Odang Hidayat, Ir.,MP. Adalah dosen Kopertis Wilayah IV yang diperbantukan pada Faperta Universitas Winaya Mukti. 